\title{
ELECTROPHORETIC PROFILE OF GOAT SEMINAL PROTEINS
}

\author{
V. C. Gajare, M. KARUnAKARAN*, A. MANDAL, M. MONDAL \\ C. BHAKAT, S. RAI, R. BEHERA AND M. K. GHOSH \\ ICAR-National Dairy Research Institute \\ Eastern Regional Station, Kalyani-741 235 \\ West Bengal, India
}

This experiment was carried out to study the electrophoretic properties of seminal proteins of Black Bengal buck semen. Semen ejaculates from nine Black Bengal bucks were used in the study. Semen ejaculates ( $n=10 /$ buck) were collected by artificial vagina. Seminal plasma and sperm were separated by centrifugation. Seminal plasma proteins were precipitated by ice cold ethanol method and sperm proteins were extracted by Triton $X$ detergent extraction method. Discontinuous sodium dodecyl sulphate polyacrylamide gel electrophoresis was performed to assess the molecular weight of seminal proteins. A total of 10 protein bands in the molecular weight ranging from 17 to $180 \mathrm{kDa}$ were found in the SDSPAGE of seminal plasma proteins while nine bands of $17 \mathrm{kDa}$ to $134 \mathrm{kDa}$ were observed in sperm proteins. Seminal plasma proteins of molecular weight 75, 62-49, 20, $17 \mathrm{kDa}$ and sperm proteins of 75 , $20,17 \mathrm{kDa}$ were present in all the 9 bucks $(100 \%)$. In conclusion variation among the bucks were noticed for presence of seminal plasma and sperm proteins and role(s) of seminal proteins on fertility needs to be studied so that they could be used as a marker for selection of breeding bucks.

Key words: Buck, Electrophoretic profile, Proteins, Semen

Animal husbandry and dairying are integral part of human life since the process of civilization started. Black Bengal breed of goat is found in West Bengal, Bihar, Jharkhand, Odisha, North Eastern India and Bangladesh. Bengal goat is very popular for its meat and skin quality, good adaptability and high fecundity. Most of the goat keepers are small, marginal farmers and landless labourers having flock size of 3 to 5 animals. In recent times, the availability of breeding bucks had become scarce due 
to castration and slaughter of male kids at early age for meat purposes (Khandoker et al., 2011). Artificial insemination (AI) technology has made possible the safe use of semen from selected sires in a large breeding female population. AI in goat is gaining popularity in several states of the country such as Tamil Nadu, Kerala, West Bengal, Assam and others for the last few years (Karunakaran et al., 2017). AI costs is reduced when compared to keeping bucks for breeding purpose in small farms and adaption AI practice provides the opportunity to access wide variety of bucks at relatively low cost. While adapting AI technology, accurate evaluation of the male fertility is important because it influences the reproductive potential of herd. Currently breeding soundness examination (BSE) is carried out before introducing a male into the semen collection programme. The variations in the fertility rate among the males were not addressed by the routine semen evaluation parameters (Larson and Miller, 2000). Attention is now being directed towards the assessment of other aspects of semen quality as predictors of fertility. Proteins present in the seminal plasma and sperm have been reported as markers of fertility (Karunakaran et al., 2012a, b). Seminal plasma, a complex mixture of secretions from testis, epididymis and accessory sex glands contained factors that modulated the fertilizing ability of sperm (Krishnan et al., 2015). Proteins such as osteopontin, prostaglandin D synthase, bovine seminal plasma proteins (BSP A1, A2, A3) and heparin binding proteins have been reported as indicators of bull fertility (Moura et al., 2006; Karunakaran and Devanathan, 2016; Krishnan et al., 2016). Agarwal et al. (2016) found differences in the seminal plasma protein profile of bucks with different semen freezability. Deori et al. (2018) reported that $60 \mathrm{kDa}$ seminal protein had huge positive connection with parameters of the fresh semen, while 47 $\mathrm{kDa}$ protein bands gave negative relationship in semen qualities of Assam Hill Goat (AHG) bucks. From the investigation they indicated that the proteins demonstrating noteworthy positive connection with fresh semen qualities might serve to screen semen of AHG bucks. AI in Black Bengal goat is gaining popularity in West Bengal and adjoining states, and it is essential to identify the bucks with better semen quality as a donor for semen collection. Presently only few studies were available on the characteristics of Black Bengal buck semen and its preservation (Konyak et al., 2018; Karunakaran et al., 2019) and there is no report available on electrophoretic properties of Black Bengal buck semen. Electrophoretic profile of seminal plasma and sperm might serve as a tool for identifying the buck semen quality and the current experiment was carried out to study the electrophoretic profile of seminal plasma and sperm proteins of Black Bengal buck semen.

\section{MATERIALS AND METHODS}

The present study was carried out at ICAR- 
National Dairy Research Institute (NDRI), Eastern Regional Station, Kalyani, West Bengal, India. The work was carried out after due approval of Institute Research Committee (IRC) of ICAR-NDRI, Karnal. Nine Black Bengal bucks (Capra hircus) were used in the study. Bucks were given with the following identification numbers 46, 48, 51, 52, 53, 55, 57, 59 and 67. All the experimental animals were clinically normal and donated semen of acceptable quality. Semen ejaculates were collected twice a week using artificial vagina. A total of 10 ejaculates form each buck and a total of ninety ejaculates were used in the study.

The seminal plasma and sperm cells were separated immediately after collection by centrifugation $\left(560 \mathrm{~g}\right.$ for $10 \mathrm{~min}$ at $5^{\circ} \mathrm{C}$ ). The sperm cells were washed with $2 \mathrm{~mL}$ of Tris calcium chloride (TC) buffer $(40 \mathrm{mM}$ Tris, $2 \mathrm{mM} \mathrm{CaCl}_{2}$ and $0.01 \%$ sodium azide, $\mathrm{pH} 7.3$ ) by centrifugation (560g for $5 \mathrm{~min}$ at $5^{\circ} \mathrm{C}$ ) to remove the left-over seminal plasma, if any. The sperm cells were resuspended with $1 \mathrm{~mL}$ of TC buffer containing protease inhibitor ( $1 \mathrm{mM}$ phenyl methyl sulfonyl fluoride) and washed thrice by centrifugation $\left(560 \mathrm{~g}\right.$ for $10 \mathrm{~min}$ at $5^{\circ} \mathrm{C}$ ). The sperm pellet and the seminal plasma were stored at $-20^{\circ} \mathrm{C}$ until extraction of protein (Karunakaran and Devanathan, 2016). Proteins in the seminal plasma were precipitated by ice-cold ethanol method (Asadpour et al., 2007). Sperm proteins were extracted by Triton $\mathrm{X}$ detergent extraction method as described by Nass et al. (1990). Discontinuous sodium dodecyl sulphate polyacrylamide gel electrophoresis (SDS-PAGE) was performed according to Laemmli (1970) with $12 \%$ resolving gel and $5 \%$ stacking gel to characterize the proteins based on molecular weight. 100 $\mu \mathrm{g}$ of seminal plasma and sperm protein samples were used to load the gel. The gels were stained with Coomassie brilliant blue and de-stained in a mixture of methanol $(25 \%)$ and acetic acid (10\%) in distilled water. The apparent molecular mass was determined by using molecular weight markers and Gel Documentation and Analysis System and the gels were stored in acetic acid (7\%).

\section{RESULTS}

Electrophoretic profile of seminal plasma proteins: A total of 10 protein bands with molecular weight ranging from $17 \mathrm{kDa}$ to $180 \mathrm{kDa}$ were observed in the SDS-PAGE of seminal plasma proteins (Table 1 and Fig. 1). The protein bands noticed in the gel were 180-136 kDa, 134 kDa-01 kDa, 75 kDa, 62 kDa-49 kDa, 48 kDa, 47 kDa-36 kDa, 35 kDa, 34 kDa-25 $\mathrm{kDa}, 20 \mathrm{kDa}$ and $17 \mathrm{kDa}$. Out of these 10 bands, proteins of $75 \mathrm{kDa}, 62 \mathrm{kDa}-49 \mathrm{kDa}$, $20 \mathrm{kDa}$ and $17 \mathrm{kDa}$ were present in all the 9 bucks (100\%), while the other protein bands such as $180 \mathrm{kDa}-136 \mathrm{kDa}, 134 \mathrm{kDa}-$ $101 \mathrm{kDa}, 48 \mathrm{kDa}, 47 \mathrm{kDa}-36 \mathrm{kDa}, 35 \mathrm{kDa}$ and $34 \mathrm{kDa}-25 \mathrm{kDa}$ were present only $55.55 \%, 55.55 \%, 33.33 \%, 44.44 \%, 44.44 \%$ and $44.44 \%$ of the bucks screened.

Electrophoretic profile of sperm proteins: Electrophoretic profile of sperm 
Indian Journal of Animal Health, June, 2019

\section{Goat seminal proteins}

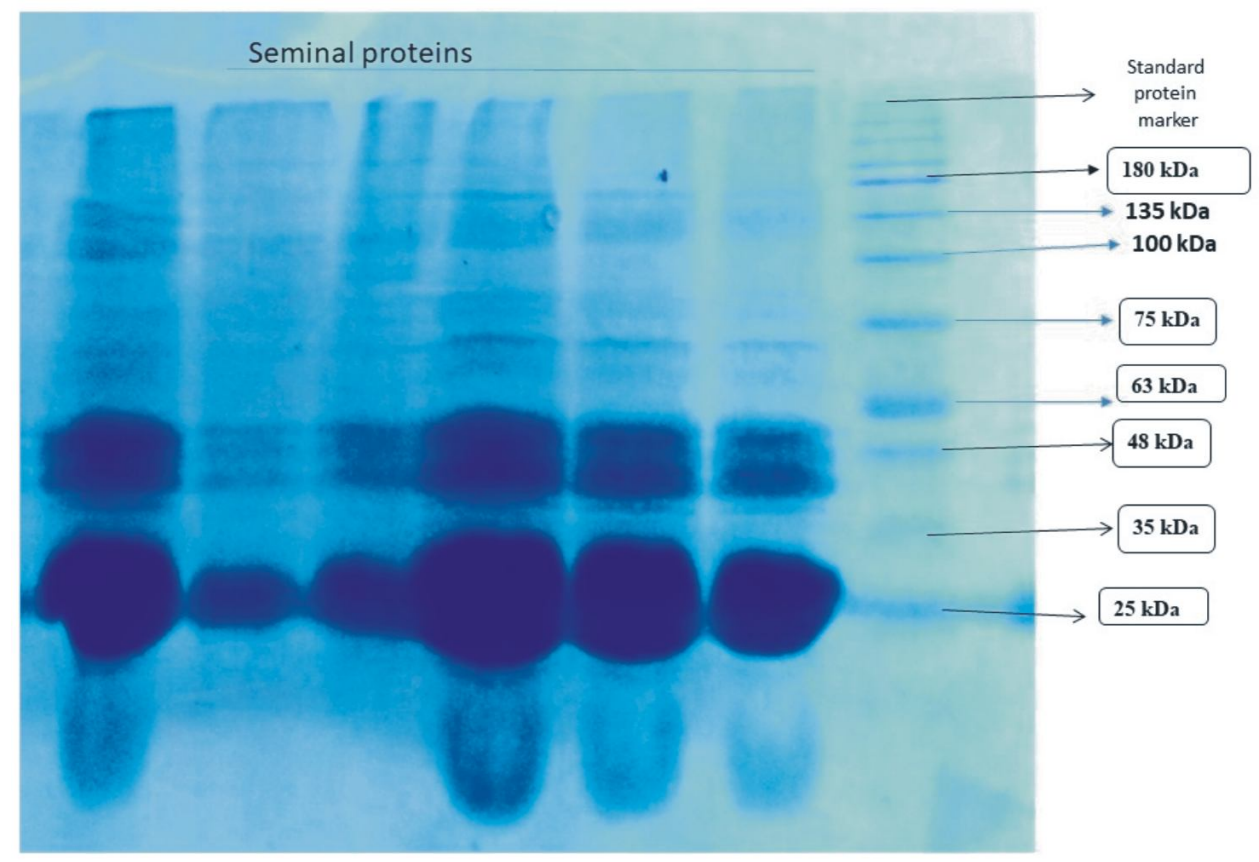

Fig. 1. Seminal plasma proteins of Black Bengal buck semen

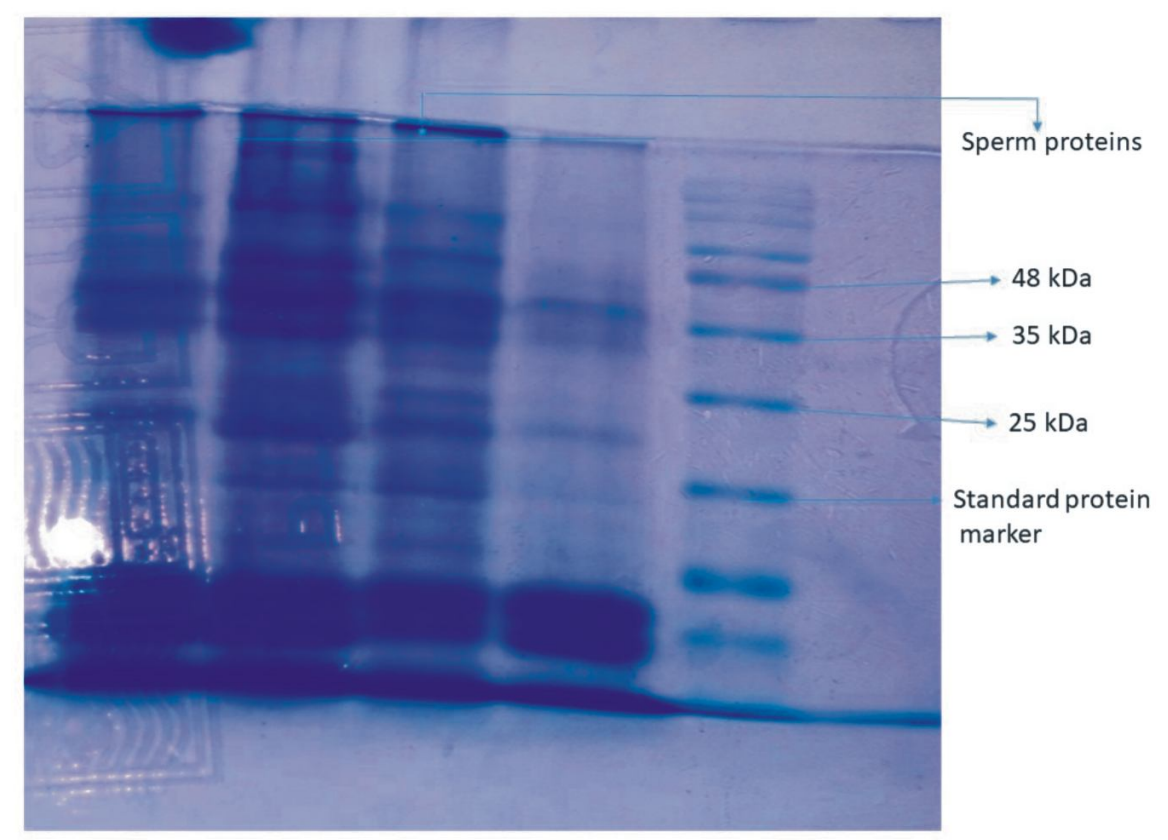

Fig. 2. Sperm proteins of Black Bengal buck semen 
proteins of Black Bengal buck semen revealed presence of nine bands starting from $17 \mathrm{kDa}$ to $134 \mathrm{kDa}$ (Table 2 and Fig. 2). Proteins with molecular weight 75 $\mathrm{kDa}, 20 \mathrm{kDa}$ and $17 \mathrm{kDa}$ were present in all the bucks screened (100\%), while the other proteins such as $134 \mathrm{kDa}-101 \mathrm{kDa}$, $100 \mathrm{kDa}, 62 \mathrm{kDa}-49 \mathrm{kDa}, 63 \mathrm{kDa}, 47 \mathrm{kDa}-$ $36 \mathrm{kDa}$ and $35 \mathrm{kDa}$ were present only in $44.44 \%, 55.55 \%, 66.66 \%, 44.44 \%, 55.55 \%$ and $33.33 \%$ of the bucks. The protein band of molecular weight $134 \mathrm{kDa}-101 \mathrm{kDa}$ was present in buck number 46, 55, 57, 59 and absent in buck number 48, 51, 52, 53 and 67 with overall presence of $44.44 \%$. The protein of molecular weight $100 \mathrm{kDa}$ was present in bucks 46, 48, 51, 52, 53, 57, 67 and absent in buck 55 and 59 with overall presence of $77.77 \%$. The protein band of molecular weight $75 \mathrm{kDa}$ was present in all the bucks. The protein band of molecular weight $62 \mathrm{kDa}-49 \mathrm{kDa}$ was present in bucks 46, 48, 51, 52, 53, 67 and absent in bucks $55,57,59$ with overall presence of $66.66 \%$. The $63 \mathrm{kDa}$ protein was present in buck number 52, 53, 55, 57, 59 and absent in 46, $48,51,67$ with overall presence of $44.44 \%$. The protein band of molecular weight 47 $\mathrm{kDa}-36 \mathrm{kDa}$ was present in buck number 46 , $51,55,57,59$ and absent in buck number $48,52,53,67$ with overall presence of $55.55 \%$. The protein band of molecular weight $35 \mathrm{kDa}$ was present in buck number $46,51,57$, and absent in buck number 48 , $52,53,55,59,67$ with overall presence of $33.33 \%$. The protein bands of molecular weight $20 \mathrm{kDa}$ and $17 \mathrm{kDa}$ were present in all the bucks.

Table 1. Electrophoretic profile of seminal plasma proteins of Black Bengal bucks assessed by SDS-PAGE

\begin{tabular}{cccccccccccc}
\hline $\begin{array}{c}\text { Protein } \\
\text { molecular } \\
\text { weight } \\
\text { (kDa) }\end{array}$ & & $\mathbf{4 6}$ & $\mathbf{4 8}$ & $\mathbf{5 1}$ & $\mathbf{5 2}$ & $\mathbf{5 3}$ & $\mathbf{5 5}$ & $\mathbf{5 7}$ & $\mathbf{5 9}$ & $\mathbf{6 7}$ & $\begin{array}{c}\text { Overall presence } \\
\text { of } \\
\text { protein no. (\%) }\end{array}$ \\
\hline $180-136$ & - & + & + & + & - & - & + & - & + & $5(55.55 \%)$ \\
$134-101$ & + & - & + & - & + & + & - & + & - & $5(55.55 \%)$ \\
75 & + & + & + & + & + & + & + & + & + & $9(100 \%)$ \\
$62-49$ & + & + & + & + & + & + & + & + & + & $9(100 \%)$ \\
48 & + & - & - & - & - & + & - & + & - & $3(33.33 \%)$ \\
$47-36$ & - & + & - & - & + & - & + & + & - & $4(44.44 \%)$ \\
35 & + & - & + & - & - & + & - & + & - & $4(44.44 \%)$ \\
$34-25$ & + & - & - & - & + & + & - & - & + & $4(44.44 \%)$ \\
20 & + & + & + & + & + & + & + & + & + & $9(100 \%)$ \\
17 & + & + & + & + & + & + & + & + & + & $9(100 \%)$ \\
\hline
\end{tabular}

(Figures in parentheses indicate percentage to total, - absence, + presence) 
Table 2. Electrophoretic profile of sperm proteins of Black Bengal bucks assessed by SDS-PAGE

\begin{tabular}{cccccccccccc}
\hline $\begin{array}{c}\text { Protein } \\
\text { molecular } \\
\text { weight } \\
\text { (kDa) }\end{array}$ & & $\mathbf{4 6}$ & $\mathbf{4 8}$ & $\mathbf{5 1}$ & $\mathbf{5 2}$ & $\mathbf{5 3}$ & $\mathbf{5 5}$ & $\mathbf{5 7}$ & $\mathbf{5 9}$ & $\mathbf{6 7}$ & $\begin{array}{c}\text { Bverall presence } \\
\text { of } \\
\text { protein no. }(\%)\end{array}$ \\
\hline $134-101$ & + & - & - & - & - & + & + & + & - & $4(44.44 \%)$ \\
100 & + & + & + & + & + & - & + & - & + & $5(55.55 \%)$ \\
75 & + & + & + & + & + & + & + & + & + & $9(100 \%)$ \\
$62-49$ & + & + & + & + & + & - & - & - & + & $6(66.66 \%)$ \\
63 & - & - & - & + & + & + & + & + & - & $4(44.44 \%)$ \\
$47-36$ & + & - & + & - & - & + & + & + & - & $5(55.55 \%)$ \\
35 & + & - & + & - & - & - & + & - & - & $3(33.33 \%)$ \\
20 & + & + & + & + & + & + & + & + & + & $9(100 \%)$ \\
17 & + & + & + & + & + & + & + & + & + & $9(100 \%)$ \\
\hline
\end{tabular}

(Figures in parentheses indicate percentage to total, - absence, + presence)

\section{DISCUSSION}

Electrophoretic profile of seminal plasma proteins: SDS-PAGE of seminal plasma proteins revealed presence of 10 protein bands with molecular weight ranging from $17 \mathrm{kDa}$ to $180 \mathrm{kDa}$ in Black Bengal buck semen. Seshagiri and Pattabiraman (1991) observed 8 protein fractions in the seminal plasma of Jersey and Sindhi bulls, and 7 protein fractions in crossbred bulls. Kulkarni et al. (1996) observed protein fractions with molecular weight ranging from $11 \mathrm{kDa}$ to $92 \mathrm{kDa}$ in cattle seminal plasma. Arangasamy et al. (2005) and Harshan et al. (2006) reported a total of 18 and 19 protein bands respectively, in buffalo seminal plasma with molecular weight ranging from $3 \mathrm{kDa}$ to
205 kDa. Teixeira et al. (2002) reported 16 protein bands with molecular weight ranging from $14 \mathrm{kDa}$ to $97 \mathrm{kDa}$ in seminal plasma proteins of Anglo-Nubian goats while studying month-wise distribution of proteins in the seminal plasma. Further they found that, the protein bands of $14 \mathrm{kDa}, 22$ $\mathrm{kDa}, 24 \mathrm{kDa}, 40 \mathrm{kDa}, 50 \mathrm{kDa}$ and $66 \mathrm{kDa}$ were distributed throughout the year in seminal plasma in Anglo-Nubian goats. Yue et al. (2009) reported a total of 15 protein bands in ram seminal plasma by SDS-PAGE with molecular weight ranging from $13 \mathrm{kDa}$ to $116.20 \mathrm{kDa}$ and found that low molecular weight proteins were predominant. The reason for the difference in the number of protein bands in the 
present study when compared with other reports might be the species/breed differences and method of protein isolation. In the present study, the seminal plasma proteins were precipitated by ice cold ethanol method while Arangasamy et al. (2005) and Harshan et al. (2006) used the seminal plasma directly for SDS- PAGE.

\section{Electrophoretic profile of sperm} proteins: Electrophoretic profile of sperm proteins of Black Bengal buck semen revealed presence of nine bands starting from $17 \mathrm{kDa}$ to $134 \mathrm{kDa}$. Some of the proteins (17 kDa, $20 \mathrm{kDa}$ and $75 \mathrm{kDa}$ ) were present in all the bucks while variations among the bucks were noticed for the presence of other proteins. Karunakaran (2011) recorded sperm proteins such as $15 / 14 \mathrm{kDa}, 28 \mathrm{kDa}$, $26 \mathrm{kDa}$ and $55 \mathrm{kDa}$ in $100 \%, 95.45 \%$, $63.64 \%$ and $50.00 \%$ of the dairy bulls screened. Nauc and Manjunath (2000) reported 3 protein fractions of BSP-A1/ A2, BSP A 3 and BSP 30 in the sperm membrane by SDS-PAGE and radio immuno-assay. They also reported a reduction in the concentration of these membrane proteins during cryopreservation. Deori et al. (2018) screened the sperm membrane proteins in Assam Hill Goat (AHG) and they had observed 20 different protein bands with molecular weight ranging from $10 \mathrm{kDa}$ to $75 \mathrm{kDa}$. Among the total 20 protein bands identified, they found only 6 bands such as $10 \mathrm{kDa}, 14 \mathrm{kDa}, 16 \mathrm{kDa}, 49 \mathrm{kDa}, 57 \mathrm{kDa}$ and $60 \mathrm{kDa}$ were consistently present in all 8 bucks. Further, they observed that the protein with molecular weight $22 \mathrm{kDa}, 30$ $\mathrm{kDa}$ and $38 \mathrm{kDa}$ showed frequency distribution of $87.50 \%, 28 \mathrm{kDa}, 45 \mathrm{kDa}$ and $47 \mathrm{kDa}$ proteins had frequency distribution of $75.00 \%$. The frequency distribution of $62.50 \%$ was showed by $24 \mathrm{kDa}, 34 \mathrm{kDa}, 55$ $\mathrm{kDa}, 59 \mathrm{kDa}$ and $70 \mathrm{kDa}$ proteins followed by $37.50 \%$ by $50 \mathrm{kDa}, 62 \mathrm{kDa}$ and $75 \mathrm{kDa}$ proteins in AHG in that study. Soubeyrand et al. (1997) purified phospholipase A2 (PLA2) from bovine seminal plasma and found it to be a $60 \mathrm{KDa}$ protein. PLA2 was also found on the plasma membrane as well as in the acrosome and post-acrosomal substance of ejaculated bull sperm (Weinman et al., 1986). This protein was reported to play an important role in the late maturational events of spermatozoa, the acrosomal reaction and sperm-egg fusion (Yuan et al., 2003).

As like that of in bovine and other species, exploration on the influence of seminal proteins on sperm functions and fertilizing ability and identification of fertility associated proteins in the buck semen will be useful for selection of breeding bucks for AI purpose.

Conflict of interest: Authors declare that there is no conflict of interest regarding the present research work. 


\section{REFERENCES}

Agarwal A, Sharma R, Roychoudhury S, Du Plessis S and Sabanegh E, 2016. MiOXSYS: a novel method of measuring oxidation reduction potential in semen and seminal plasma. Fertil Steril, 106(3): 566573

Arangasamy A, Singh LP, Ahmed NM, Ansari $\mathrm{R}$ and $\mathrm{Ram} \mathrm{GC}, 2005$. Isolation and characterization of heparin and gelatin binding buffalo seminal plasma proteins and their effect on cauda epididymal spermatozoa. Anim Reprod Sci, 90: 243254

Asadpour R, Alavi-Shoushtari SM, Rezaii SA and Ansari MK, 2007. SDSpolyacrylamide gel electrophoresis of buffalo bulls seminal plasma proteins and their relation with semen freezability. Anim Reprod Sci, 102(3-4): 308-313

Deori S, Deka B, Biswas R, Nahardeka N, Arangasamy A et al., 2018. Characteristics and freezability of Assam Hill Goat semen. Indian J Anim Res, 52 (1): 25-28

Harshan HM, Singh LP, Arangasamy A, Ansari MR and Kumar S, 2006. Effect of buffalo seminal plasma heparin binding protein (HBP) on freezability and in vitro fertility of buffalo cauda spermatozoa. Anim Reprod Sci, 93: 124-133

Karunakaran M, 2011. Evaluation of bull semen quality in-relation to fertility associated proteins, in vitro sperm characters and lipid peroxidation. Ph.D. Thesis, TANUVAS, Chennai-600 051, Tamil Nadu, India
Karunakaran M, Devanathan TG, Jawahar TP, Manimaran K, Chitra A et al., 2012a. Electrophoretic profile of bull sperm membrane proteins as a tool for selection of breeding bulls. Indian J Anim Sci, 82: 1303-1305

Karunakaran M, Devanathan TG, Kulasekar K, Sridevi P, Jawahar TP et al., 2012b. Effect of heparin binding protein and hydrogen peroxide on lipid peroxidation status of bovine sperm cells. Indian J Anim Sci, 82(9): 976-978

Karunakaran M and Devanathan TG, 2016. Evaluation of bull semen for fertilityassociated protein, in vitro characters and fertility. J Appl Anim Res, 45(1): 136-144

Karunakaran M, Konyak P, Mandal A, Mondal M, Bhakat C et al., 2017. Chemically welldefined extender for preservation of Black Bengal buck semen. Res Rev: J Dairy Sci Technol, 6(2): 7-10

Karunakaran M, Konyak P, Mandal A, Mondal M, Bhakat C et al., 2019. Effect of trehalose- an impermeant cryo-protectant on cryopreservation of Black Bengal buck semen. Indian J Anim Res, 53(1): 37-40

Khandoker MAMY, Apu AS, Husain SS and Notter DR, 2011. A baseline survey on the availability of Black Bengal breeding bucks in different districts of Bangladesh. J Bangladesh Agricul Univ, 9(1): 91-96

Konyak P, Mandal A, Mondal M, Bhakat C, Das SK et al., 2018. Preservation of Black Bengal buck semen in soybean lecithin based chemically defined extender. Indian J Anim Res, 52(8): 1151-1154 
Krishnan G, Thangvel A, Loganathasamy K, Veerapandian C, Kumarasamy $\mathrm{P}$ et al., 2015. Effect of fertility associated proteins on lipid peroxidation production in Holstein Friesian semen. Indian J Anim Sci, 85 (11): 1176-1180

Krishnan G, Thangvel A, Loganathasamy K, Veerapandian C, Kumarasamy $\mathrm{P}$ et al., 2016. The presence of heparin binding proteins and their impact on semen quality of Holstein Friesian bulls. Indian J Anim Sci, 86(4): 392-396

Kulkarni BA, Dhande SG and Patankar DD, 1996. Seminal plasma protein profiles of Holstein Friesian, Jersey and crossbred bulls. Indian J Anim Sci, 11: 133-137

Laemmli VK, 1970. Cleavage of structural proteins during the assembly of the head of bacteriophage T4. Nature, 227: 660-685

Larson JL and Miller DJ, 2000. Can relative spermatozoal galactosyltransferase activity be predictive of dairy bull fertility? J Dairy Sci, 83: 2473-2479

Moura AA, Koc H, Chapman DA and Killian GJ, 2006. Identification of proteins in the accessory sex gland fluid associated with fertility indexes of dairy bulls: a proteomic approach. J Androl, 27(2): 201-211

Nass SJ, Miller DJ, Winner MA and Ax RL, 1990. Male accessory sex glands produce heparin-binding proteins that bind to cauda epididymal spermatozoa and are testosterone dependent. Mol Reprod Dev, 25: $237-246$
Nauc V and Manjunath P, 2000. Radioimmunoassays for bull seminal plasma proteins (BSP-A1/-A2, BSP-A3, and BSP30 -Kilodaltons) and their quantification in seminal plasma and sperm. Biol Reprod, 63 (4): 1058-1066

Seshagiri VN and Pattabiraman SR, 1991. Characterization of seminal plasma proteins of Sindhi, Jersey and crossbred bulls. Indian Vet J, 68: 1143-1146

Soubeyrand S, Khadir A, Brindle Y and Manjunath P, 1997. Purification of a novel phospholipase A2 from bovine seminal plasma. J Biol Chem, 272: 222-227

Teixeira D, Cavada B, Sampaio A, Havt A, Bloch JC et al., 2002. Isolation and partial characterisation of a protein from buck seminal plasma (Capra hircus), homologous to Spermadhesins. Protein Pept Lett, 9(4): 331-335

Weinman S, Ores Carton D, Rainteau D and Puszkin S, 1986. Immunoelectron microscopic localization of calmodulin and phospholipase A2 in spermatozoa. $\mathbf{J}$ Histochem Cytochem, 34: 1171-1179

Yuan YY, Chen WC, Shi QX, Mao LM, Yu Q et al., 2003. Zona pellucida induces activation of phospholipase A2 during acrosomal exocytosis in guinea pig spermatozoa. Biol Reprod, 68: 904-913

Yue W, Shi L, Bai Z, Ren Y and Zhoa Y, 2009. Sodium dodecyl sulfate (SDS) polyacrylamide gel electrophoresis of ram seminal plasma proteins and their correlation with semen characteristics. Anim Reprod Sci, 116: 386-391 